\title{
SISTEM PEMILIHAN KEPALA DAERAH \\ PADA DAERAH YANG MEMBERLAKUKAN \\ DESENTRALISASI ASIMETRIS
}

\author{
Ali Muhammad Johan C. ${ }^{1}$ \\ alimjohan@yahoo.com \\ Dewan Perwakilan Rakyat Daerah Provinsi DKI Jakarta \\ Jln. Kebon Sirih No. 18, Gambir, Jakarta Pusat, DKI Jakarta
}

\begin{abstract}
Abstrak
Berdasarkan Pasal 18B UUD NRI 1945, Indonesia menerapkan desentralisasi asimetris dengan mendasarkan pada kekhususan dan keistimewaan daerah, termasuk dalam hal sistem pemilihan kepala daerah. Namun keragaman sistem pemilihan tersebut bukan berarti tanpa batas, melainkan harus sejalan dengan prinsip demokratis dalam Pasal 18 ayat (4) UUD NRI 1945. Penelitian ini hendak menelaah sistem pemilihan kepala daerah yang digunakan oleh daerah yang memberlakukan desnetralisasi asimetris. Jenis penelitian yang digunakan adalah penelitian normatif dengan pendekatan deskriptif. Hasil penelitian menyimpulkan, bahwa dari empat daerah yang memberlakukan desentralisasi asimetris, hanya tiga daerah yang kepala daerahnya dipilih melalui sistem yang demokratis, dan masih ada satu daerah yang sistem pemilihan kepala daerahnya tidak demokratsi.
\end{abstract}

Kata Kunci: Desentalisasi Asimetris, Sistem Pemilihan, Pemilihan Kepala Daerah.

\section{Abstact}

Based on Article 18B of the 1945 Constitution, Indonesia implements asymmetric decentralization by basing on regional specificities and privileges, including in terms

\footnotetext{
${ }^{1}$ Anggota Dewan Perwakilan Rakyat Daerah Provinsi DKI Jakarta.
} 


\section{AL-QISTH LAW REVIEW \\ VOL 5 NO. 1 (2021)}

of regional head election systems. But the diversity of the electoral system does not mean without limits, but must be in line with democratic principles in Article 18 paragraph (4) of the 1945 Constitution. This study is to study the regional head selection system used by regions that enforce asymmetrical desnetrization. The type of research used is normative research with a descriptive approach. The results concluded, that of the four regions that impose asymmetric decentralization, only three regions whose regional heads are elected through a democratic system, and there is still one area whose regional head election system is not democratic.

Keywords: Asymmetrical Desentization, Electoral System, Regional Head Elections.

\section{A. PENDAHULUAN}

\section{a. Latar Belakang Masalah}

Salah satu isyu krusial dalam hukum tata negara di Indonesia adalah hubungan antara pemerintahan di tingkat pusat dan pemerintahan di tingkat lokal atau daerah. Hal ini adalah wajar, mengingat fakta sejarah bahwa sejak sebelum Indonesia di proklamirkan pada 17 Agustus 1945 dan memiliki konstitusi pertama pada 18 Agustus 1945, daerah-daerah di Indonesia telah sejak awal memiliki pemerintahan yang eksis, walaupun pada umumnya bercorak monarki.

Menurut C.S.T. Kansil (Kansil, 1991), sejak sebelum kemerdekaan telah banyak peraturan yang dibuat untuk mengatur persoalan pemerintahan di daerah dan persoalan yang berkaitan dengan desentralisasi. Sejak tahun 1903, setidaknya ada 2 (dua) peraturan yang dikeluarkan dalam kaitannya dengan pemerintahan di daerah, yakni Decentralisatie Wet Tahun 1903 dan Bestuur S.H.ervormin Tahun 1922. 


\section{AL-QISTH LAW REVIEW \\ VOL 5 NO. 1 (2021)}

Setelah kemerdekaan, permasalahan tetang hubungan pemerintahan pusat dan daerah masih menyisahkan banyak persoalan. Berbagai persoalan ini terutama disebabkan oleh situasi politik baik pada masa Orde Lama maupun Orde Baru yang cenderung otoriter dan sentralistik, sehingga daerah tidak mendapatkan kemandiriannya untuk mengembangkan potensi didaerah. Kenyataan inilah yang hendak dikoreksi oleh arus reformasi, sehingga isyu tentang otonimi daerah cukup mendominasi pada saat perubahan Undang-Undang Dasar Negara Republik Indonesia Tahun 1945 (selanjutnya disingkat UUD NRI 1945).

Perubahan sistem kekuasaan Negara pasca reformasi tahun 1998, terutama pelaksanaan Undang-Undang Nomor 22 Tahun 1999 tentang Pemerintahan Daerah (yang direvisi dengan UU No. 32 Tahun 2004) memberi peluang otonomi daerah yang luas. Pengertian otonomi daerah menurut UU No. 32 Tahun 2004 sebagai amandemen UU No. 22 Tahun 1999 adalah hak, wewenang, dan kewajiban daerah otnom untuk mengatur dan mengurus sendiri urusan pemerintahan dan kepentingan masyarakat masyarakat setempat sesuai dengan peraturan perundang-undangan. Sejak diberlakukannya UU No. 22 Tahun 1999, orientasi pembangunan diubah dari prinsip efisiensi dan pertumbuhan menjadi prinsip kemandirian dan keadilan. Dalam kondisi orientasi pembangunan yang demikian, maka orientasi penyelenggaraan pembangunan bergeser kearah desentralisasi. (Muqoyyudin, 2013, p. 288) 


\section{3}

\section{AL-QISTH LAW REVIEW \\ VOL 5 NO. 1 (2021)}

Sejalan dengan hal tersebut, Eko Sabar Prihatin (Prihatin, 2014) mengemukakan bahwa seiring dengan era transisi dari otoritarianisme menuju proses demokratisasi dalam konteks kehidupan berbangsa dan bernegara di indonesia, yang kemudian diikuti dengan hadirnya kebijakan otonomi daerah, maka sebenarnya kita dapat melihat minimal ada 3 (tiga) perubahan politik hukum otonomi daerah, yaitu;

Pertama, perubahan dari sentralisasi kekuasaan menjadi desentralisasi kewenangan. Dalam perspektif ini, di masa "Orde Baru" misalnya, Otonomi Daerah tidak lebih dari sekedar penyerahan kewenangan oleh Pusat kepada daerah dalam konteks administratif belaka, sedangkan saat ini, konsep Otonomi mencakup kewenangan yang luas dan nyata, dimana Pemerintah daerah berhak mengatur dan mengurus kepentingan masyarakat di daerah sesuai dengan prakarsa dan aspirasi masyarakat setempat. Kewenangan daerah mencakup kewenangan dalam seluruh urusan pemerintahan kecuali kewenangan dalam bidang, (i). Politik luar negeri, (ii). Pertahanan, (iii), keamanan, (iv). Yustisi / Peradilan, (v). Moneter dan fiskal nasional, dan (vi). Agama, yang disebutkan dalam Pasal 10 ayat (3) Undang-Undang No. 32 tahun 2004, tentang Pemerintahan Daerah.

Kedua, perubahan dari manajemen pemerintahan yang otoritarian menjadi berorientasi kepada egalitarian dan demokrasi. Di masa Orde Baru misalnya, kebijakan otonomi daerah diletakkan dalam kerangka otoritarianisme kekuasaan, kebijakan yang top down dan sentralisasi 


\section{4}

\section{AL-QISTH LAW REVIEW \\ VOL 5 NO. 1 (2021)}

pembangunan, sehingga daerah hanya dieksploitasi sumber daya alamnya saja, daerah menjadi "sapi perahan" oleh pemerintah pusat tanpa diimbangi dengan pemerataan pembangunan. Sedangkan saat ini otonomi daerah berada dalam kerangka demokratisasi serta sentralisasi pembangunan, dimana daerah diberi kewenangan untuk mengurus daerahnya sendiri.

Ketiga, perubahan dari sistem perwakilan menjadi sistem pemilihan secara langsung. Dalam konteks ini dimasa lalu pemilihan kepala daerah dengan menggunakan sistem perwakilan, dimana kepala daerah dipilih oleh anggota DPRD yang merupakan representasi dari rakyat didaerah yang dipilih melalui pemilihan umum, sedangkan sekarang ini kepala daerah dipilih secara langsung oleh masyarakat di daerahnya.

Dalam UUD NRI 1945 pasca amandemen, hubungan Pemerintah Pusat dan Pemerintah Daerah diatur dalam Pasal 18A UUD NRI Tahun 1945 menyatakan bahwa:

(1) hubungan wewenang antara pemerintah pusat dan pemerintahan daerah provinsi, kabupaten dan kota, atau antara provinsi dan kabupaten dan kota, diatur dengan undang-undang dengan memperhatikan kekhususan dan keragaman daerah;

(2) hubungan keuangan, pelayanan umum, pemanfaatan sumber daya alam dan sumber daya lainnya antara pemerintah pusat dan pemerintah daerah diatur dan dilaksanakan secara adil dan selaras berdasarkan undang-undang. 


\section{5}

\section{AL-QISTH LAW REVIEW \\ VOL 5 NO. 1 (2021)}

Frasa "dengan memperhatikan kekhususan dan keragaman daerah" dalam Pasal 18A ayat (1) UUD NRI Tahun 1945 ini sebenarnya mengindikasikan bahwa konstitusi menghendaki adanya pengaturan yang berbeda bagi tiap-tiap daerah yang mempunyai corak khusus dan beragam. Hal ini semakin diperkuat dengan adanya Pasal 18B UUD NRI Tahun 1945 yang menentukan:

(1) Negara mengakui dan menghormati satuan-satuan pemerintahan daerah yang bersifat khusus atau bersifat istimewa yang diatur dengan undang-undang;

(2) Negara mengakui dan menghormati kesatuan-kesatuan masyarakat hukum adat beserta hak-hak tradisionalnya sepanjang masih hidup dan sesuai dengan perkembangan masyarakat dan prinsip Negara Kesatuan Republik Indonesia, yang diatur dalam undang-undang.

Dengan demikian, politik hukum (legal policy) tentang desentralisasi yang digariskan UUD NRI Tahun 1945 mengisyaratkan keniscayaan penerapan "desentralisasi asimetris" yang menekankan kekhususan, keistimewaan, keberagaman daerah, serta kesatuan-kesatuan masyarakat hukum adat dan hak-hak tradisional yang diatur lebih lanjut dengan undang-undang. (Tauda, 2018)

Desentralisasi asimetris (asymmetrical decentralisation) adalah pemberlakuan/transfer kewenangan khusus yang hanya diberikan pada daerah-daerah tertentu dalam suatu negara, yang dianggap sebagai alternatif untuk menyelesaikan permasalahan hubungan antara 


\section{6}

\section{AL-QISTH LAW REVIEW \\ VOL 5 NO. 1 (2021)}

pemerintah pusat dan pemerintah daerah, dalam konteks Indonesia dalam rangka menjaga eksistensi daerah dalam NKRI. Desentralisasi asimetris mencakup desentralisasi politik, ekonomi, fiskal, dan administrasi, namun tidak harus seragam untuk semua wilayah negara, dengan mempertimbangkan kekhususan masing-masing daerah. Penerapan kebijakan desentralisasi asimetris merupakan sebuah manifestasi dari usaha pemberlakuan keistimewaan. Konsep tersebut sebenarnya sudah dijalankan dalam praktik ketatanegaraan Republik Indonesia, yaitu dengan adanya beberapa daerah yang berstatus istimewa/berotonomi khusus seperti Provinsi Papua \& Papua Barat, Provinsi Aceh, Provinsi Daerah Khusus Ibukota Jakarta, dan Provinsi Daerah Istimewa Yogyakarta. Keempat provinsi ini secara legal formal sudah memperoleh pengakuan dari negara. Inti desentralisasi asimetris adalah terbukanya ruang gerak implementasi dan kreativitas provinsi dalam pelaksanaan pemerintahan daerah di luar ketentuan umum dan khusus yang diatur dalam UndangUndang Nomor 23 Tahun 2014 tentang Pemerintahan Daerah, ataupun peraturan perundang-undangan lainnya.

Dari keempat cakupan desentralisasi asimetris, bidang politik cukup menarik perhatian. Pada kenyataannya desentralisasi asimetris bidang politik menyisahkan permasalahan baik dibidang hukum maupaun dalam praktinya. Sebagaimana diketahui, desentralisasi asimetris dibidang politik ini tercermin dalam sistem pemilihan kepala daerah di keempat daerah (DKI Jakarta, Papua, Aceh, dan Yogyakarta), di mana masing-masing menggunakan sistem yang berbeda-beda. Menurut Saldi Isra, bila dilacak 


\section{AL-QISTH LAW REVIEW \\ VOL 5 NO. 1 (2021)}

aspek model pengisian jabatan kepala daerah, empat daerah daerah khusus atau istimewa tersebut adalah, Daerah Istimewa Yogyakarta yang memiliki sistem pengisian jabatan gubernur dan wakil gubernur yang berbeda dari yang lain. Dalam hal ini, Aceh, DKI Jakarta dan Papua sama-sama menggunakan sistem pemilihan langsung, di mana gubernur dan wakil gubernurnya dipilih langsung oleh rakyat. Walaupun demikian, sistem pemilihan langsung tersebut, terdapat varian-varian yang berbeda antara daerah yang satu dengan daerah yang lainya: (Isra, 2018)

Pertama, untuk Provinsi Papua, terdapat beberapa aturan pelaksanaan pemilihan kepala daerah yang berbeda dengan pengaturan penyelenggaraan secara umum. Dalam pelaksanaan di Papua dan Papua Barat, terdapat syarat calon kepala daerah yang mesti adalah orang Papua asli. Jikalau dikaitkan dengan persyarakat pencalonan yang berlaku di dalam UU Pemilihan Kepala Daerah, ketentuan yang membatasi calon dapat mengajukan diri menjadi kepala daerah dan wakil kepala daerah kepala daerah di papua hanya untuk orang papua asli, tentu saja menimbulkan ketidaksamaan kesempatan berpartisipasi dalam pemerintahan. Hanya saj, karena secara sosiologis, menimbang aspek sejarah serta penghormatan terhadap struktur masyarakat hukum adat yang berlaku khusus dan spesifik di Papua, perbedaan syarat menjadi calon kepala daerah tidak dianggap bertentangan dengan UUD NRI 1945.

Kedua, pemilihan kepala daerah Aceh juga terdapat pengaturan penyelenggaraan yang berbeda dengan aturan yang berlaku umum. 


\section{8}

\section{AL-QISTH LAW REVIEW \\ VOL 5 NO. 1 (2021)}

Misalnya, dari nomenklatur penamaan penyelenggaraan pemilihan umum, di Aceh tidak dinamai dengan Komisi Pemilihan Umum (KPU), melainkan Komisi Independen Pemilihan (KIP) Aceh untuk tingkat Provinsi dan KIP Kabupaten/Kota untuk tingkat Kabupaten/Kota. Selain itu, untuk jumlah dan mekanisme pengisian penyelenggaraan pemilihan umum di Aceh juga berbeda dari daerah lain.

Ketiga, pemilihan Gubernur dan Wakil Gubernur DKI Jakarta. Paling tidak, ada dua aspek pemilihan yang berbeda antara DKI Jakarta dengan daerah lainnya. Pertama, di DKI Jakarta, pemilihan kepala daerah hanya terjadi untuk pemilihan gubernur dan wakil gubernur saja. Sementara untuk walikota di lima kota administrative di DKI Jakarta, pengisiannya melalui penunjukan oleh gubernur. Begitu juga bupati yang masuk wilayah administrative Jakarta, pengisiannya dilakukan dengan penunjukkan oleh gubernur. Selain itu, syarat perolehan suara untuk terpilih dalam pemilihan gubernur dan wakil gubernur juga berbeda dengan daerah lainnya, terutama terbuka kemungkinan dilaksanakannya pemilihan dengan dua putaran. Hal demikian terjadi apabila pada putaran pertama tidak terdapat pasangan calon yang memperoleh suara lebih 50\% dari total suara sah. Jika terjadi putaran kedua, maka pemilihan putaran kedua akan diikuti oleh peraih suara terbanyak pertama dan kedua pada pemilihan putaran pertama.

Keempat, terkait dengan pemilihan kepala daerah di Yogyakarta. Dalam UU No. 13 Tahun 2012 tentang Keistimewaan Daerah Istimewa 


\section{AL-QISTH LAW REVIEW \\ VOL 5 NO. 1 (2021)}

Yogyakarta diatur bahwa tidak ada pemilihan langsung untuk pengisian Gubernur dan Wakil Gubernurr Yogyakarta. Dalam hal ini, Pasal 18 ayat (1) huruf c UU No. 13 Tahun 2012 menyatakan syarat menjadi gubernur dan wakil gubernur adalah bertakhta sebagai Sultan Hamengku Buwono untuk calon gubernur dan bertakhta sebagai Adipati Paku Alam untuk calon wakil gubernur. Artinya, Sulatan Hamengku Buwono dan Adipati Paku Alam yang bertakhta secara otomatis menjadi Gubernur dan Wakil Gubernur Yogyakarta tanpa ada pemilihan lagi, baim oleh rakyat Yogyakarta maupun ole DPRD.

Adanya variasi/perbedaan sistem pemilihan kepala daerah di keempat daerah di atas merupakan pengejawantahan Pasal 18B ayat (1) dan ayat (2) UUD NRI 1945 yang menjadi basis konstitusional desentralisasi asimetris, termasuk di bidang politik. Perbedaan sistem ini adalah konsekuensi dari pengakuan dan penghormatan negara terhadap kekhususan dan keistimewaan daerah-daerah tertentu. Akan tetapi jika menyangkut pemilihan kepala daerah, maka tidak cukup cukup hanya mendasarkan pada Pasal 18B ayat (1) dan ayat (2) UUD NRI 1945. Secara spesifik yang menjadi dasar konstitusional pemilihan kepala daerah justru diatur dalam Pasal 18 ayat (4) UUD NRI 1945: “Gubernur, Bupati, dan Walikota masing-masing sebagai kepala pemerintah daerah provinsi, kabupaten dan kota dipilih secara demokratis".

Norma inilah (Pasal 18 ayat (4) UUD NRI 1945) yang menjadi rujukan utama ketika membahas pemilihan kepala daerah. Adapun yang 


\section{0}

\section{AL-QISTH LAW REVIEW \\ VOL 5 NO. 1 (2021)}

menjadi kata kunci dari Pasal 18 ayat (4) UUD NRI 1945 adalah 'kepala daerah dipilih secara demokratis'. Jika dihubungkan dengan Pasal 18B ayat (1) dan ayat (2) UUD NRI 1945, maka diphami bahwa keragaman (asimetris) sistem pemilihan kepala daerah di keempat daerah yang telah disebutkan, tidak boleh bertentangan dengan nilai-nilai demokrasi. Artinya, secara konstitusional daerah-daerah yang khusus dan istimewa dapat saja memiliki keragaman (asimetris) dalam hal sistem pemilihan kepala daerah, sepanjang sejalan dan tidak bertentangan dengan prinsip demokratis.

Penelitian ini dimaksudkan untuk meneliti hal dimaksud, yakni apakah keragaman (asimetris) sistem pemilihan kepala daerah di keempat daerah (DKI Jakarta, Papua dan Papua Barat, Aceh, dan DI Yogyakarta) yang memberlakukan desentralisasi asimetris, sejalan dan tidak bertentangan dengan prinsip 'dipilih secara demokratis' berdasarkan Pasal 18 ayat (4) UUD NRI 1945.

\section{b. Rumusan Masalah}

Berangkat dari uraian pada bagian latar belakang masalah di atas, maka penelitian ini ingin menjawab pertanyaan sebagai berikut:

1. Bagaimanakah sistem pemilihan kepala daerah menurut UndangUndang Dasar Negara Republik Indonesia Tahun 1945?

2. Apakah sistem pemilihan kepala daerah di daerah yang memberlakukan desentralisasi asimetris, bersesuaian dengan sistem pemilihan kepala daerah menurut Pasal 18 ayat (4) UD NRI 1945? 


\section{1}

\section{AL-QISTH LAW REVIEW \\ VOL 5 NO. 1 (2021)}

\section{c. Metode Penelitian}

Penelitian ini adalah jenis penelitian hukum normatif yang menggunakan pendekatan deskriptif. Penelitian hukum normatif yakni penelitian hukum yang dilakukan dengan cara meneliti bahan pustaka atau data sekunder belaka, jenis penelitian inilah yang dikatakan sebagai penelitian hukum normatif. Penelitian hukum normatif mencakup: (i) penelitian terhadap asas-asas hukum; (ii) penelitian terhadap sistematika hukum; (iii) penelitian terhadap taraf singkronisasi vertical dan horizontal; (iv) perbandingan hukum; dan, (v) sejarah hukum. (Soekanto, 2010)

Secara spesifik jenis penelitian yang memfokuskan pada bahan hukum, baik yang bersifat primer, sekuder, tersier. Bahan hukum primer adalah data yang berbentuk Peraturan Peraturan Perundang-Undangan, sedangkan bahan hukum sekunder meliputi Buku-Buku, Artikel Ilmiah, Hasil Penelitian, dan Laporan yang dikeluarkan Lembaga Resmi.

Adapun pendekatan penelitian deskriptif sebagaimana dikemuakan Soerjono Soekanto, suatu penelitian deskriptif dimaksudkan untuk memberikan data yang seteliti mungkin tentang manusia, keadaan atau gejala-gejala lainnya. Maksudnya adalah terutama untuk mempertegas hipotesa-hipotesa, agar dapat membantu di dalam memperkuat teori-teori lama, atau di dalam kerangka menyusun teori-teori baru. (Soekanto, Soerjono, 2014) 


\section{2}

\section{AL-QISTH LAW REVIEW \\ VOL 5 NO. 1 (2021)}

\section{B. PEMBAHASAN}

\section{a. Sistem Pemilihan Kepala Daerah Menurut UUD NRI 1945}

Salah satu wujud dan mekanisme demokrasi di daerah adalah pelaksanaan pemilihan kepala daerah. Pemilihan kepala daerah merupakan sarana manifestasi kedaulatan dan pengukuhan bahwa pemilih adalah masyarakat di daerah. Pemilihan Kepala daerah memilik 3 (tiga) fungsi penting dalam penyelenggaraan pemerintahan daerah. Pertama, memilih kepala daerah sesuai dengan kehendak masyarakat di daerah sehingga ia diharapkan dapat memahami dan mewujudkan kehendak masyarakat di daerah. Kedua, melalui pemilihan kepala daerah diharapkan pilihan masyarakat di daerah didasarkan pada visi, misi, program serta kualitas dan integritas calon kepala daerah, yang sangat menentukan keberhasilan penyelenggaraan pemerintahan di daerah. Ketiga, pemilihan kepala daerah merupakan sarana pertanggungjawaban sekaligus sarana evaluasi dan kontrol public secara politik terhadap seorang kepala daerah dan kekuatan politik yang menopangnya. (Gaffar, 2010)

Pasca amandemen UUD NRI 1945, perihal pemilihan kepala daerah secara spesifik diatur dalam Pasal 18 ayat (4) UUD NRI 1945 yang selengkapnya menetukan: “Gubernur, Bupati, dan Walikota masing-masing sebagai kepala pemerintah daerah provinsi, kabupaten dan kota dipilih secara demokratis". Kata kunci dalam Pasal 18 ayat (4) UUD NRI 1945 di atas adalah pemilihan kepala daerah 'dipilih secara demokratis'. Konstitusi 


\section{3}

\section{AL-QISTH LAW REVIEW \\ VOL 5 NO. 1 (2021)}

tidak menentukan secara spesifik sistem yang harus digunakan, melainkan memberikan ruang untuk memilih sistem manapun, sepanjang sistem tersebut memenuhi prinsip pemilihan yang demokratis.

Secara historis, lahirnya kata demokratis dalam Pasal 18 ayat (4) Undang-Undang Dasar pada saat dilakukan perubahan UUD 1945 terdapat adanya 2 (dua) pendapat yang berbeda mengenai cara pemilihan kepala daerah. Satu pendapat menghendaki pemilihan kepala daerah secara langsung oleh rakyat maupun DPRD sementara pendapat lain menghendaki tidak dilakukan secara langsung oleh rakyat. (Hsb, 2016)

Diantara yang mengusulkan agar pemilihan kepala daerah dipilih secara langsung ole rakyat adalah Anthonius Rahail dari Fraksi KKI (2010: 1235), yang menyatakan:

“.... ini ingin kami tekankan, karena selama ini pemilihan tidak langsung dan akhir-akhir ini justru hasil pemilihan bupati dan gubernursetelah melaksanakan pemerintahannya ternyata tidak menunjukkan kemampuan yang berarti untuk membangun rakyat dan nampaknya nanti yang susah juga adalah rakyat itu sendiri. Oleh karena itu, menyangkut tentang sistem pemilihan eksekutif ini memang perlu kita tetapkan secara benar apa yang menurut kata hati kita sekarang adalah terbaik untuk membangun bangsa dan negara ini. Oleh karena itu kami melihat, bahwa contoh-contoh yang ada sekarang, kadangkala dengan sistem yang tidak langsung itu lalu bisa atur akhirnya menghasilkan orang yang punya uanglah yang jadi. Itu adalah suatu fakta seperti itu.

Oleh karena itu kami mengusulkan yang pertama di mana gubernur, bupati dan walikota itu dipilih secara langsung. Saya 


\section{4}

\section{AL-QISTH LAW REVIEW \\ VOL 5 NO. 1 (2021)}

yakin dan percaya, bahwa sudah cukup banyak kaderkader bangsa kita yang tersebar di seluruh tanah air hanya kesempatan yang barangkali perlu kita berikan, sehingga ada kompetitif yang sehat dalam rangka kita mempunyai kader pemimpin rakyat yang memang betul-betul teruji kepemimpinannya oleh penilaian secara terbuka, terimakasih pak."

Sedangkan yang mengusulkan agar pemilihan kepada daerah dipilih secara demokratis adalah Hobbes Sinagari F-PDIP yang mengatakan:

"Jadi, kita tidak dipilih secara langsung oleh rakyat tapi dipilih secara demokratis, itu usulan kita. Bukan, inikan begini ya, dalam hal inikan saya kira kan ini perdebatan kita yang utama nanti adalah masalah pemilihan presiden, masalah pemilihan gubernur dan selanjutnya, jadi saya kira harus dihormati juga usulan kita yang seperti itu begitu, jadi saya kira nanti di untuk ayat (4) ini bikin alternatiflah ya, dilaternatif dipilih secara demokratis yang selanjutnya diatur dalam undang-undang. Alternatif, jadi bikin alternatif ayat."

Berdasarkan perbedebatan yang berkembang dalam proses terbentuknya rumusan Pasal 18 ayat (4) UUD NRI 1945 di atas, maka dipahami bahwa UUD NRI 1945 pasca amandemen menghendaki agar sistem pemilihan kepala dareah adalah asimetris (beragam), bukan simetris (seragam). Pemilihan kepala daerah asismetris berdasarkan Pasal 18 ayat (4) UUD NRI 1945 ini juga telah memiliki tafsir konstitusional, melalui setidaknya dalam 2 (dua) Putusan Mahkamah Konstitusi. 


\section{5}

\section{AL-QISTH LAW REVIEW \\ VOL 5 NO. 1 (2021)}

Pertama, dalam putusan Mahkamah Konstitusi Nomor 97/PUUXI/2013, latar belakang pemikiran lahirnya rumusan Pasal 18 ayat (4) UUD 1945 saat itu adalah sistem pemilihan kepala daerah yang akan diterapkan disesuaikan dengan perkembangan masyarakat dan kondisi di setiap daerah yang bersangkutan. Pembentuk undang-undang dapat merumuskan sistem pemilihan yang dikehendaki oleh masyarakat di dalam pemilihan kepala daerah sehingga masyarakat mempunyai pilihan apakah akan menerapkan sistem perwakilan yang dilakukan oleh DPRD atau melalui sistem pemilihan secara langsung oleh rakyat. Tujuannya adalah agar menyesuaikan dengan dinamika perkembangan bangsa untuk menentukan sistem demokrasi yang dikehendaki oleh rakyat. Hal ini merupakan opened legal policy dari pembentuk undang-undang dan juga terkait erat dengan penghormatan dan perlindungan konstitusi terhadap keragaman adat istiadat dan budaya masyarakat di berbagai daerah yang berbeda-beda. Ada daerah yang lebih cenderung untuk menerapkan sistem pemilihan tidak langsung oleh rakyat dan ada pula daerah yang cenderung dan lebih siap dengan sistem pemilihan langsung oleh rakyat. Baik sistem pemilihan secara langsung (demokrasi langsung) maupun sistem pemilihan secara tidak langsung (demokrasi perwakilan) samasama masuk kategori sistem yang demokratis. Berdasarkan Putusan Mahkamah Konstitusi Nomor: 97/PUU-XI/2013 disimpulkan bahwa baik pemilihan secara langsung oleh rakyat maupun pemilihan secara tidak langsung sama-sama masuk dalam kategori demokratis. Tetapi, dengan syarat bahwa pemilihan tersebut dilaksanakan dengan menerapkan asas- 


\section{6}

\section{AL-QISTH LAW REVIEW \\ VOL 5 NO. 1 (2021)}

asas pemilihan umum secara demokratis yaitu: langsung, umum, bebas, rahasia, jujur dan adil. (Hsb, 2016, p. 233)

Pemilukada asimetris berdasarka Pasal 18 ayat (4) UUD NRI 1945 bahkan lebih tegas disebutkan dalam Putusan Mahkamah Konstitusi Nomor 072-073/PUUII/2004 dinyatakan bahwa merupakan wewenang pembentuk undang-undang untuk menentukan apakah pemilukada dilakukan secara langsung atau tidak. Bahkan, sesuai dengan latar belakang pembahasan ketentuan pemilukada dalam UUD 1945, pembuat undang-undang sesungguhnya juga dapat menentukan sistem pemilukada berbeda-beda sesuai dengan daerah masing-masing. Jika di Jakarta pemilukada dilakukan secara langsung, tidak berarti di Yogyakarta juga harus demikian, demikian pula di Papua serta daerah lain. Hal ini sesuai dengan keragaman masyarakat Indonesia, baik dilihat dari adat, struktur masyarakat maupun tingkat kesiapannya.

Disamping tafsir dalam 2 (dua) Putusan Mahkamah Konstitusi di atas, tafsir "dipilih secara demokratis" dalam Pasal 18 ayat (4) UUD NRI 1945 sebagai sistem pilkada asistemtris, juga dikemukakan oleh Jimly Asshiddiqie (2002: 22). Menurutnya, perkataan "dipilih secara demokratis" ini bersifat luwes, sehingga mencakup pengertian pemilihan langsung oleh rakyat ataupun oleh Dewan Perwakilan Rakyat Daerah (DPRD) seperti yang pada umumnya sekarang dipraktekan didaerah-daerah berdaarkan ketentuan peraturan perUndang-Undangan yang berlaku. 


\section{7}

\section{AL-QISTH LAW REVIEW \\ VOL 5 NO. 1 (2021)}

Berdasarkan analisis di atas, maka pemilihan kepala daerah menurut Pasal 18 ayat (4) UUD NRI 1945 pasca amandemen memang dimaksudkan menganut sistem pilkada asimetris (beragam). Artinya, sitem pemilihan kepala daerah itu dapat beragam (asimetris), apakah dipilih secara langsung atau diplih melalui DPRD. Akan tetapi, pilihan sistem tersebut harus sejalan dan tidak boleh bertentangan dengan prinsip demokrasi.

\section{b. Sistem Pemilihan Kepala Daerah Di Empat Daerah Yang Memberlakukan Desentralisasi Asimetris.}

Saat ini terdapat 4 (empat) daerah yang memberlakukan desentralisasi asimetris berdasarkan Pasal 18B ayat (1) dan (2) UUD NRI 1945, yakni: (1) Daerah Khusus Ibukota Jakarta berdasarkan UndangUndang Nomor 29 Tahun 2007 tentang Pemerintahan Provinsi Daerah Khusus Ibukota Jakarta Sebagai Ibukota Negara Kesatuan Republik Indoneseia; (2) Daerah Istimewa Yogyakarta berdasarkan Undang-Undang Nomor 13 Tahun 2012 tentang Keistimewaan Daerah Istimewa Yogyakarta; (3) Papua berdasarkan Undang-Undang Nomor 21 Tahun 2001 tentang Otonomi Khusus Bagi Provinsi Papua; dan, (4) Aceh berdasarkan UndangUndang Nomor 11 Tahun 2006 tentang Pemerintahan Aceh. Berdasarkan pengaturan di dalam setiap Undang-Undang bagi keempat daerah tersebut, terdapat pengaturan yang berbeda dari daerah-daerah lain pada umunya, sebagai bentuk dari desentralisasi asimetris dengan mendasarkan pada kekhususan dan keistimewaan masing-masing daerah. Hal ini juga 


\section{8}

\section{AL-QISTH LAW REVIEW \\ VOL 5 NO. 1 (2021)}

berlaku dalam hal desentralisasi asimetris di bidang politik, yang tercermin dalam sistem pemilihan kepala daerah yang juga beragam (asimetris) dari keempat daerah tersebut.

\section{Provinsi DKI Jakarta}

Desentralisasi asimetris di bidang politik pada Provinsi DKI Jakarta tercermin dari sistem pemilihan kepala daerahnya. Hal ini tercermin dalam 2 (dua) hal (Isra, Saldi, 2018):

Pertama, di DKI Jakarta pemilihan kepala daerah hanya terjadi untuk pemilihan gubernur dan wakil gubernur saja. Sementara untuk walikota di lima kota administratif di DKI Jakarta, pengisiannya melalui penunjukan oleh gubernur. Begitu juga juga dengan bupati yang masuk wilayah administratif Jakarta, pengisiannya dilakukan dengan penunjukkan oleh gubernur. Hal ini sebagaimana diatur dalam Pasal 19 ayat (1) dan ayat (2) UU No. 29 Tahun 2007:

(1) Kota administrasi/kabupaten administrasi dipimpin oleh walikota/bupati;

(2) Walikota/bupati diangkat oleh Gubernur atas pertimbangan DPRD Provinsi DKI Jakarta dari pegawai negeri sipil yang memenuhi persyaratan.

Kedua, adalah dalam hal syarat perolehan suara untuk calon terpilih dalam pemilihan gubernur dan wakil gubernur juga memiliki perbedaan dengan daerah lainnya, terutama terbukanya kemungkinan 


\section{AL-QISTH LAW REVIEW \\ VOL 5 NO. 1 (2021)}

dilaksanakannya pemilihan dengan dua putaran. Hal demikian terjadi apabila pada putaran pertama tidak terdapat pasangan calon yang memperoleh suara lebih dari 50\% dari total suara sah. Jika terjadi putaran kedua, maka pemilihan putaran kedua akan diikuti oleh perai suara terbanyak pertama dan kedua pada pemilihan putaran pertama. Hal ini sebagaimana diatur dalam Pasal 11 ayat (1), (2), dan ayat (3) UU No. 29 Tahun 2007:

(1) Pasangan calon Gubernur dan Wakil Gubernur yang memperoleh suara lebih dari 50\% (lima puluh persen) ditetapkan sebagai Gubernur dan Wakil Gubernur terpilih.

(2) Dalam hal tidak ada pasangan calon Gubernur dan Wakil Gubernur yang memperoleh suara sebagaimana dimaksud pada ayat (1), diadakan pemilihan Gubernur dan Wakil Gubernur putaran kedua yang diikuti oleh pasangan calon yang memperoleh suara terbanyak pertama dan kedua pada putaran pertama.

(3) Penyelenggaraan pemilihan Gubernur dan Wakil Gubernur sebagaimana dimaksud pada ayat (1) dan ayat (2) dilaksanakan menurut persyaratan dan tata cara yang diatur dalam peraturan perundangundangan.

\section{Provinsi Papua}

Desentralisasi asimetris di bidang politik tercermin dari sistem pemilihan yang meliputi meliputi 3 (tiga) hal: (1) Adanya persyaratan khusus bagi calon gubernur dan wakil gubernur Orang Asli Papua, 


\section{0}

\section{AL-QISTH LAW REVIEW \\ VOL 5 NO. 1 (2021)}

yakni orang yang berasal dari rumpun ras Melanesia yang terdiri dari suku-suku asli di Provinsi Papua dan/atau orang yang diterima dan diakui sebagai orang asli Papua oleh masyarakat adat Papua; (2) tata cara pemilihan gubernur dan wakil gubernur Papua ditetapkan dengan Peraturan Daerah Khusus (Perdasus) sesuai dengan peraturan perundang-undangan; dan, (3) sistem pemilihan melalui mekanisme Noken di wilayah tertentu.

Jika dihubungkan dengan Pasal 18 ayat (4) UUD NRI 1945, maka perbedaan (asimetris) sistem pilkada di Provinsi Papua, maka sistem pemilihan kepala daerah asimetris di Papua adalah masih sejalan dan tidak bertentangan dengan nilai-nilai demokratis. Hal ini dikarenakan pada prinsipnya sistem pilkada yang berlaku di Papua masih dilaksanakan melalui mekanisme pemilu langsung oleh rakyat. Adapun 3 (tiga) sub-sistem yang membedakannya dengan daerah lain, pada prinsipnya tidak bertentangan dengan nilai demokrasi.

Dalam hal persyaratan calon kepala daerah yang harus orang asli papua, hal ini justru dimaksudkan untuk memperkuat desentralisasi yang memprioritaskan penduduk lokal. Hal yang sama juga berlaku bagi pemberlakukan Peraturan Daerah Khusus (Perdasus) dalam hal pengaturan Pilkada. Hal yang demikian sedikitpun tidak menyalahi prinsip demokratis, termasuk penggunaan sistem noken yang tidak mengurangi makna pemilihan itu sendiri sebagai perwujudan prinsip demokratis. 


\section{1}

\section{AL-QISTH LAW REVIEW \\ VOL 5 NO. 1 (2021)}

\section{Provinsi Aceh}

Desentralisasi asimetris di bidang politik yang berlaku tercermin dari sistem pemilihan yang meliputi meliputi 5 (lima) hal: (1) penyelenggaraan Pemilihan Kepala Daerah (Pilkada) di Aceh yang berpedoman pada Qanun Aceh; (2) Penyelengga pilkada yang dilaksanakan oleh Komisi Independen Pemilina (KIP); (3) Pengawas Pemilihan dilaksanakan oleh Panitia Pengawas Pemilihan (Panwaslih) untuk mengawasi jalannya penyelenggaraan Pilkada; (4) Adanya persyaratan berupa kewajiban menjalankan syariat agamanya bagi calon kepala daerah di Aceh yang salah satunya melalui uji kemampuan membaca Al-Quran; (5) Syarat dukungan bagi calon perseorangan yang hanya sebesar 3\% (tiga persen) dari jumlah penduduk yang tersebar di sekurang-kurangnya 50\% (lima puluh persen) Kabupaten/Kota untuk Pilgub dan sekurang-kurangnya 50\% (lima puluh persen) Kecamatan untuk Pilbub/Pilwakot.

\section{Provinsi DI Yogyakarta}

Desentralisasi asimetris di bidang politik pada Provinsi DI Yogyakarta, tercermin dari sistem pemilihan Gubernur dan Wakil Gubernur, yang setidaknya meliputi 3 (tiga) hal: (1) Persyaratan sebagai calon Gubernur dan calon Wakil Gubernur, yakni syarat menjadi Gubernur adalah bertakhta sebagai Sultan Hamengku Buwono dan syarat menjadi Wakil Gubernur adalah bertakhta sebagai Adipati Paku Alam; (2) tidak ada pemilihan umum, baik secara langsung oleh rakyat 


\section{2}

\section{AL-QISTH LAW REVIEW \\ VOL 5 NO. 1 (2021)}

maupun melalui DPRD; dan, (3) Masa jabatan Gubernur dan Wakil Gubernur adalah 5 (lima) tahun, tetapi tidak terikat pada ketentuan 2 (dua) kali periodisasi masa jabatan.

Ketiga hal adalah sistem yang tidak sejalan dan bertentangan dengan prinsip demokratis. Hal ini dikarenakan dalam pengisian jabatan Gubernur dan Wakil Gubernur di DI Yogyakarta, tidak dilakukan melalui mekanisme pemilihan, baik langsung oleh rakyat maupun melalui DPRD. Hal ini dikarenakan pengisian kepala daerah dilakukan melalui sistem monarki, di mana ada persyaratan menjadi Gubernur adalah bertakhta sebagai Sultan Hamengku Buwono dan syarat menjadi Wakil Gubernur adalah bertakhta sebagai Adipati Paku Alam. Hal ini secara langsung menutup dilaksanakannya sistem pilkada yang demokratis sesuai amanat Pasal 18 ayat (4) UUD NRI 1945.

\section{c. Desentralisasi Asimetris Di Bidang Yang Demokratis}

Jika melihat kepada keragaman (asimetris) sistem pemilihan kepala daerah yang diberlakukan di keempat daerah sebagaimana diuraiakn di atas, maka perlu dilakukan analisis mendalam, apakah kergaman sistem tersebut, sejalan dengan prinsip demokratis. Dalam hal ini, secara konstitusional desentralisasi asimetris (khususnya dibidang politik) yang diamanatkan Pasal 18B UUD NRI 1945 wajib sejalan dengan sistem 


\section{3}

\section{AL-QISTH LAW REVIEW \\ VOL 5 NO. 1 (2021)}

pemilihan kepala daerah yang digariskan dalam Pasal 18 ayat (4) UUD NRI 1945.

Berdasarkan uraian di atas, maka dari 4 (empat) daerah yang memberlakukan desentralisasi asimetris di Indonesia berdasarkan Pasal 18B ayat (1) dan ayat (2) UUD NRI 1945, hanya sistem pilkada di Provinsi DI. Yogyakarta saja yang sitem pemilihan kepala daerahnya tidak sesuai dengan amanat Pasal 18 ayat (4) UUD NRI 1945. Hal ini dikarenakan sistem yang digunakan di Provinsi DI Yogyakarta bukanlah pemilhan, baik langsung oleh rakyat maupun melalui DPRD, melainkan dilakukan melalui pengangkatan secara otomatis, yakni yang menjadi Gubernur adalah bertakhta sebagai Sultan Hamengku Buwono dan yang menjadi Wakil Gubernur adalah bertakhta sebagai Adipati Paku Alam.

Sedangkan untuk 3 (tiga) daerah lainnya, yakni Provinsi DKI Jakarta, Provinsi Papua, dan Provinsi Aceh, sistem pemilihan kepala daerah yang berlaku adalah sejalan dengan amanat Pasal 18 ayat (4) UUD NRI 1945, yakni menggunakan sistem yang demokratis. Dalam hal ini, di keempat wilayah tersebut sejatinya memang menggunakan sistem pemilihan langsung oleh rakyat, hanya saja terdapat kekhususan tersendiri sebagai konsekuensi dari status daerah tersebut sebagai daerah yang bersifat khusus/istimewa berdasarkan Pasal 18B ayat (1) dan ayat (2) UUD NRI 1945.

Untuk Provinsi DKI Jakarta misalnya, jika dihubungkan dengan Pasal 18 ayat (4) UUD NRI 1945, maka perbedaan (asimetris) sistem pilkada 


\section{4}

\section{AL-QISTH LAW REVIEW \\ VOL 5 NO. 1 (2021)}

di DKI Jakarta sebenarnya masih sejalan dan prinsip dan nilai-nilai demokrasi. Pilkada yang hanya sampai pada level Gubernur dan Wakil Gubernur, justru merupakan konsekuensi DKI Jakarta sebagai Ibukota Negara dan berstatus daerah khusus (special region), substansi kekhususan Jakarta terlihat meninjol pada bentuk pemerintahan berotonomi tunggal (single autonomy) di level Provinsi. (Jaweng, Robertus Na Endi, 2012)

Adapun untuk Provinsi Papua, jika dihubungkan dengan Pasal 18 ayat (4) UUD NRI 1945, maka perbedaan (asimetris) sistem pilkada di Provinsi Papua masih sejalan dan tidak bertentangan dengan nilai-nilai demokratis. Hal ini dikarenakan pada prinsipnya sistem pilkada yang berlaku di Papua masih dilaksanakan melalui mekanisme pemilu langsung oleh rakyat. Adapun 3 (tiga) sub-sistem yang membedakannya dengan daerah lain, pada prinsipnya tidak bertentangan dengan nilai demokrasi. Dalam hal persyaratan calon kepala daerah yang harus orang asli papua, hal ini justru dimaksudkan untuk memperkuat desentralisasi yang memprioritaskan penduduk lokal. Hal yang sama juga berlaku bagi pemberlakukan Peraturan Daerah Khusus (Perdasus) dalam hal pengaturan Pilkada. Hal yang demikian sedikitpun tidak menyalahi prinsip demokratis, termasuk penggunaan sistem noken yang tidak mengurangi makna pemilihan itu sendiri sebagai perwujudan prinsip demokratis.

Hal yang sama juga bagi Provinsi Aceh. Jika dihubungkan dengan Pasal 18 ayat (4) UUD NRI 1945, maka perbedaan (asimetris) sistem pilkada 


\section{5}

\section{AL-QISTH LAW REVIEW \\ VOL 5 NO. 1 (2021)}

di Provinsi Aceh masih berlandaskan prinsip demokratis, karena sejatinya sistem yang berlaku adalah pemilihan langsung oleh rakyat. Adapun 5 (lima) sub-sistem yang membedakannya dengan daerah lain, pada prinsipnya tidak bertentangan dengan nilai demokrasi. Pertama adalah penyelenggaraan pilkada yang berpedoman pada Qanun, sejatinya tidak mengurangi makna pemilihan langsung itu sendiri, termasuk di dalamnya nilai-nilai demokrasi. Begitu juga keberadaan KIP (Komisi Independen Pemilina) dan Panwaslih (Panitia Pengawas Pemilihan) dalam hal penyelenggara pilkada, juga hanya dimaksdukan sebagai ciri khas Provinsi Aceh yang tidak mengurai makna demokrasi. Hal yang yang juga berlaku bagi adanya persyaratan berupa kewajiban menjalankan syariat agamanya bagi calon kepala daerah di Aceh yang salah satunya melalui uji kemampuan membaca Al-Quran, tidak bisa dipandang bertentangan dengan prinsip demokratis.

\section{PENUTUP}

Berdasarkan analisis yang terurai pada bagian pembahasan, maka tulisan ini menaik kesimpulan sebagai berikut:

1. Pasca amandemen UUD NRI 1945, konstitusi tidak menentukan secara spesifik sistem pemilihan kepala daerah yang berlaku. Merujuk pada Pasal 18 ayat (4) UUD NRI 1945, konstitusi hanya menghendaki sistem pemilihan yang demokratis, artinya, sitem pemilihan kepala daerah itu dapat beragam (asimetris), apakah 


\section{6}

\section{AL-QISTH LAW REVIEW}

VOL 5 NO. 1 (2021)

dipilih secara langsung atau diplih melalui DPRD, ataupun menggunakan sistem lain sepanjang memenuhi prinsip dipilih secara demokratis.

2. Dari keempat daerah yang memberlakukan desentralisasi asimetris berdasatkan Pasal 18B UUD NRI 1945, terdapat 3 daerah yakni Provinsi DKI Jakarta, Provinsi Papua, dan Provinsi Aceh dengan sistem pemilihan pemilihan kepala daerah yang bersesuaian dengan prinsip demokratis sebagaimana diatur dalam Pasal 18 ayat (4) UUD NRI 1945. Adapun khusus untuk Provinsi DI Yogyakarta, sistem pemilihan yang digunakan tidak bersesuaian dengan prinsip demokrais berdasarkan Pasal 18 ayat (4) UUD NRI 1945. 


\section{AL-QISTH LAW REVIEW}

VOL 5 NO. 1 (2021)

\section{DAFTAR PUSTAKA}

Asshiddiqie. J. (2002). konsulidasi Naskah UUD 1945 setelah perubahan ke empat, Depok: Pusat studi hukum Tata Negara Fakultas Hukum Universitas Indonesia.

Gaffar. J. M. (2010). Politik Hukum Pemilu, Jakarta: Konstitusi Press, 2010.

Hsb. A. M. (2016). Pemilihan Kepala Daerah Yang Demokratis Berdasarkan Putusan Mahkamah Konstitusi Nomor 97/PUU-IX/2013, Jurnal Legislasi Indonesia, Vol. 13, No. 03.

Isra. S. (2018). Desentrlisasi Asimetris Di Indonesia", Orasi Ilmiah pada Rapat Senat Terbuka dalam Rangka Dies Natalis Ke-72 Fakultas Hukum Universitas Gadjah Mada, Yogyakarta.

Jaweng. R. N. E. (2012). Analisis Kewenangan Khusus Jakarta Sebagai Ibukota Negara Dalam Konteks Desentralisasi Di Indonesia, Tesis. Program Pascasarjana Fakultas Ilmu Sosial Dan Ilmu Politik Universitas Indonesia.

Kansil. C.S.T. (1991). Pokok-Pokok Pemerintahan di Daerah, cdt. Ke-3, Jakarta: Rineka Cita. 


\section{8}

\section{AL-QISTH LAW REVIEW \\ VOL 5 NO. 1 (2021)}

Muqoyyudin. A. W. (2013). Pemekaran Wilayah dan Otonomi Daerah Pasca Reformasi di Indonesia: Konsep, Fakta Empiris, dan Rekomendasi ke Depan. Jurnal Konstitusi, Vol. 10, No. 2.

Prihatin. E. S. (2014). Politik Hukum Otonomi Daerah Tentang Pemilukada. Jurnal MMH, Jilid 43, No. 1.

Soekanto. S. (2014). Pengantar Penelitian Hukum, Jakarta: Penerbit Universitas Indonesia.

Soekanto. S. dan Mamudji. S. (2010). Penelitian Hukum: Suatu Tinjauan Singkat, Jakarta: Rajawali Press.

Tim Penyusun. (2010). Naskah Konprehensip Buku Jilid 4 Kekuasaan Pemerintahan Negara, Jakarta: Sekretariat Jenderal Dan Kepaniteraan Mahkamah Konstitusi.

Tauda. G. A. (2018). Desain Desentralisasi Asimetris Dalam Sistem Ketatanegaraan Republik Indonesi. Administrative Law \& Governance Journal, Vol. 1, Edisi 4. 